\title{
ANALISIS FAKTOR KENDALA INDUSTRI KECIL MENENGAH (STUDI PADA IKM MAKANAN DI KELURAHAN TIDAR UTARA KOTA MAGELANG)
}

\author{
Maya Noura Nazifah', Khairul Ikhwan ${ }^{2}$ \\ 1Universitas Tidar, Magelang, Jawa Tengah, Indonesia \\ ${ }^{2}$ Universitas Tidar, Magelang, Jawa Tengah, Indonesia \\ mayanaura281@gmail.com
}

\begin{abstract}
Abstrak: Industri Kecil Mikro sektor makanan menghadapi tantangan yang terus bertambah besar dibalik berkembangnya teknologi informasi. Sementara itu, IKM sektor makanan masih mengalami kendala mendasar yang belum terpecahkan. Penilitian ini, bertujuan menganalisis faktor apa saja yang menjadi kendala usaha yang dialami oleh Industri Makanan yang ada di Kelurahan Tidar Utara, Kota Magelang. Teknik pengumpulan data pada penelitian ini survei menggunakan instrumen kuesioner dan wawancara. Data dianalisis menggunakan analisis deskriptif kualitatif. Penelitian ini menguraikan serta menganalisis faktor kendala usaha pada industri makanan di Kelurahan Tidar Utara, Kota Magelang. Total sampel sebanyak 65 IKM makanan. Hasil penelitian menunjukkan bahwa terdapat 3 kendala utama yang mempengaruhi serta menghambat kinerja IKM makanan di Kelurahan Tidar Utara Kota Magelang. Kendala tersebut yaitu: pemasaran, permodalan, dan pembukuan. Solusi atas kendala tentu saja tidak hanya dibebankan pada IKM sendiri, tetapi juga harus memperoleh dukungan dari dari asosiasi pengusaha maupun dari lingkungan pemerintah.
\end{abstract}

Kata Kunci: Kendala Usaha; Industri Makanan; IKM (Industri Kecil Menengah)

Abstract: Small and Micro Industry, the food sector faces the growing challenges behind the development of information technology. Meanwhile, the food sector IKM is still experiencing fundamental obstacles that have not been resolved. This research aims to analyze what factors are the business constraints experienced by the Food Industry in North Tidar Village, Magelang City. The data collection technique in this research was a survey using a questionnaire and interview instruments. Data were analyzed using qualitative descriptive analysis. This study describes and analyzes the factors of business constraints in the food industry in Tidar Utara Village, Magelang City. A total sample of 65 food IKMs. The results showed that 3 main obstacles affect and hinder the performance of food IKMs in Tidar Utara Village, Magelang City. These constraints are: marketing, capital, and bookkeeping. The solution to these obstacles is of course not only borne by the IKM itself, but also must obtain support from employers' associations and the government.

Keywords: Business Constraints; Food Industry; IKM (Small and Medium Industry). 


\section{PENDAHULUAN}

Saat ini IKM (Industri Kecil Menengah) menjadi salah satu sektor yang memiliki peran guna mendorong perekonomian daerah. Selain itu IKM juga berperan penting dalam hal produksi dan pendistribusian produk-produk yang dihasilkan kepada masyarakat dan juga dalam hal penyerapan tenaga kerja. IKM menjadi sektor yang cukup tangguh dalam menghadapi permasalahan ekonomi daerah, maka dari itu pemerintah setempat setidaknya memiliki perhatian lebih pada perkembangan sektor IKM. Proses pengembangan industri IKM, ada beberapa hal yang perlu diperhatikan yaitu dengan melihat atau mengetahui kendala suatu usaha.

Disperindag (Dinas Perindustrian dan Perdagangan) Kota Magelang memiliki berbagai wewenang guna membantu berjalannya ekonomi usaha agar terus berkembang. Keberadaan industri kecil menengah (IKM) di Kota Magelang hingga saat ini cukup besar. Pada tahun 2018, Dinas Perindustrian dan Perdagangan (Disperindag) mencatat ada sekitar 7.557 IKM dengan omset penjualan tiap bulan Rp 72,6 miliar dan serapan tenaga kerja mencapai 14.115 orang. IKM yang terdaftar di Disperindag terdiri dari: usaha mikro sebanyak 7.078 usaha, lalu 455 usaha kecil, dan 24 usaha menengah. Namun dibalik itu, beberapa masalah yang kerap muncul adalah kualitas produk yang belum sesuai pasar. Begitu pula kendala di pemasaran dan permodalan yang terbatas, jaringan usaha kecil, mental sumber daya manusia (SDM) yang lemah, sarana yang masih tradisional, dan juga pencatatan pembukuan yang masih belum diatur.

Industri menjadi salah satu mata pencahariaan masyarakat di Kota Magelang, khususnya di Kelurahan Tidar Utara. Industri yang cukup berkembang di wilayah tersebut adalah industri atau usaha makanan berskala kecil maupun sedang. (Sri Adiningsih, 2013)dalam penelitiannya, menyatakan bahwa UKM/IKM yang terbukti mempunyai kontribusi yang baik terhadap perekonomian negara, ternyata masih memiliki berbagai macam kendala yang fundamental, bahkan UKM/IKM di Indonesia masih memiliki manajemen usaha yang kurang bagus. Tak terkecuali pada industri makanan, (Taib dan Roswita, 2018) menyatakan bahwa industri makanan dalam skala kecil mempunyai potensi untuk dikembangkan, khususnya dalam era perdagangan bebas. Daya saing produk makanan lokal juga harus ditingkatkan dengan memperhatikan berbagai kondisi yang mempengaruhi perkembangannya, khususnya tentang bagaimana model pengemasan, proses produksi maupun pemasarannya. Pemerintah berkomitmen membantu mengurangi permasalahan IKM yang ada. Upaya pemerintah diantaranya memberikan motivasi, memfasilitasi hingga mendampingi, mengadvokasi kemajuan serta perkembangan IKM dengan mengutamakan pola pembinaan piranti lunak dan piranti keras secara simultan dan komprehensif.

Sedikitnya literatur yang menjelaskan tentang kendala IKM secara terperinci di Kota Magelang menjadi salah satu alasan penulis untuk melakukan penelitian ini. Pada artikel yang berjudul "Analisis Determinasi 
Pendapatan Usaha Industri Mikro Kecil Tahu Di Trunan, Tidar Selatan, Magelang Selatan, Kota Magelang" oleh (Setiaji dan Khoirudin, 2018) mengungkapkan bahwa wilayah dari Kota Magelang tidaklah terlalu luas dan sektor pertanian atau sektor lainnya belum bisa diandalkan untuk menopang perekonomian di Kota Magelang. Sektor industri menjadi salah satu sektor ekonomi yang mampu menyerap tenaga kerja dan pendapatan ekonomi masyarakat Kota Magelang. Permasalahan yang umum dijumpai IKM Kota Magelang yaitu permodalan atau SDM (tenaga kerja). Kendala permodalan dan tenaga kerja dapat mempengaruhi bagaimana tumbuh dan berkembangya suatu industri. Modal akan mempengaruhi skala usaha yang pada akhirnya akan mempengaruhi besar atau kecilnya jumlah produksi suatu usaha industri tahu (Setiaji dan Khoirudin, 2018). Tenaga kerja juga mempengaruhi pendapatan dengan bertambahnya tenaga kerja yang digunakan akan membuat semakin cepatnya proses produksi dan bisa juga menambah hasil produksi dan akan menambah juga pendapatan para pengusaha tahu di Trunan Kelurahan Tidar Selatan Kecamatan Magelang Selatan Kota Magelang.

Berdasarkan latar belakang tersebut, maka menarik untuk melakukan penelitian mengenai apa saja kendala yang dihadapi oleh para pelaku usaha kecil maupun sedang yang ada di Kelurahan Tidar Utara, Kota Magelang. Penelitian ini juga menganalisis upaya Disperindag dalam mendukung para pelaku usaha industri makanan untuk terus berkembang.

\section{METODE PENELITIAN}

Penelitian ini diadakan di beberapa IKM khususnya IKM makanan yang ada di Kelurahan Tidar Utara Kota Magelang. Waktu pelaksanan dalam penelitian ini yaitu dari tanggal 14 Januari 13 Februari 2020. Penelitian ini berdasarkan arahan pembina UMKM Dinas Perindustrian dan Perdagangan Kota Magelang di wilayah Kelurahan Tidar Utara. Data yang digunakan dalam penelitian ini berupa data primer dan data skunder. Data primer berasal dari survei menggunakan instrumen kuesioner dan wawancara. Data sekunder diperoleh dari studi literatur. Studi literatur digunakan untuk memperluas pemahaman dan mendukung analisis penelitian.

Populasi dalam penelitian ini yaitu semua IKM makanan yang ada di Kelurahan Tidar Utara Kota Magelang. Teknik pengambilan sampel yang digunakan yaitu purposive sampling dengan ketentuan IKM makanan yang melalui tahap pendataan oleh Disperindag Kota Magelang di wilayah Kelurahan Tidar Utara pada tahun 2019, dengan jumlah sampel sebesar 65 IKM. Metode Analisis yang digunakan pada penelitian ini yaitu analisis deskriptif kualitatif, yang berarti analisis dengan menguraikan serta menganalisis kendala-kendala yang dihadapi oleh IKM pada industri makanan dalam menjalankan usahanya. Berdasarkan data yang ada yaitu data primer, data tersebut diolah kemudian di analisis untuk memperoleh gambaran tentang kendala yang dialami oleh para pelaku usaha serta untuk mengetahui langkah dan solusi apa yang diberikan kepada Dinas 
Perindustrian dan Perdagangan Kota Magelang.

\section{HASIL DAN PEMBAHASAN}

Perusahaan atau industri dalam hal menjalankan kegiatan produksinya membutuhkan beberapa sumber daya ekonomi, seperti halnya bahan baku, permodalan, sumber daya manusia, mapun fasilitas atau peralatan yang mampu digunakan dan dimanfaatkan secar optimal. Pada kenyataannya, setiap industri mengalami keterbatasan sumber daya produksi yang disebut kendala atau constraint. Suatu kendala memiliki dampak tersendiri bagi Perusahaan atau industri dalam melakukan kegiatan produksi.

IKM sektor makanan di Kelurahan Tidar Utara memiliki beberapa kendala dalam pengembangan usahanya. Kendala yang dihadapi IKM sektor makanan di Kelurahan Tidar Utara terdiri dari kendala internal dan eksternal. Menurut Warcito dan Ramly (2020)Beberapa masalah yang menjadi kendala baik internal maupun eksternal dalam hal manajemen dan kegiatan operasional bisnis IKM, antara lain: (1) UMK masih memiliki modal rendah, (2) pengetahuan IKM masih rendah dalam mengembangkan dunia bisnis, (3) ketersediaan fasilitas dan infrastruktur yang dibutuhkan oleh pelaku IKM masih rendah, (4) IKM masih mengalami kendala lingkungan eksternal (eksternal) seperti kurangnya listrik, (5) IKM masih belum dapat memahami strategi \& proses pemasaran untuk hasilnya. produksi, (6) kurangnya pemahaman tentang mekanisme birokrasi di dunia bisnis, (7) kemampuan untuk mengoperasionalkan teknologi yang masih rendah, dan (8) kemampuan IKM untuk mengakses informasi masih terbatas.

\section{Kendala Internal Dan Eksternal}

(1) Kendala Internal, dalam industri kendala internal berarti suatu masalah yang muncul dari dalam yang mengakibatkan suatu hambatan dalam proses produksi. Selain itu, masalah tersebut juga dapat mempengaruhi aktivitas usaha yang lain. Industri Kecil Menengah(IKM) yang ada di wilayah Kelurahan Tidar Utara, Kota Magelang, para pelaku usaha mengalami berbagai macam kendala internal, yaitu : Pemasaran, (2) Permodalan, (3) Pembukuan, dan (4) SDM (Sumber Daya Manusia).

(2) Kendala Eksternal, dalam industri usaha kendala eksternal dapat berarti suatu masalah yang muncul dari luar atau disebabkan oleh faktor eksternal (luar) yang mengakibatkan suatu permasalahan dalam proses usaha produksi. Industri Kecil Menengah (IKM) yang ada di wilayah Kelurahan Tidar Utara, Kota Magelang, para pelaku usaha mengalami kendala yaitu masalah perizinan dan juga bahan baku.

(3) Kendala Utama, Di Kota Magelang, Disperindag (Dinas Perindustrian dan Perdagangan) memiliki berbagai wewenang yang salah satunya dari sentra industri. Menurut situs web Disperindag, di Kota Magelang, sentra industri ada 2 yaitu sentra tahu dan sentra roti/kue. Namun lebih daripada itu, Disperindag melakukan pendataan satu persatu kepada pelaku usaha guna mendapatkan informasi seputar kendala maupun pengembangan usaha. 
Berikut ini adalah grafik jumlah kendala Industri Kecil Menengah Kelurahan Tidar Utara pada sektor makanan dengan data yang bersumber dari Dinas Perindustrian dan Perdagangan Kota Magelang.

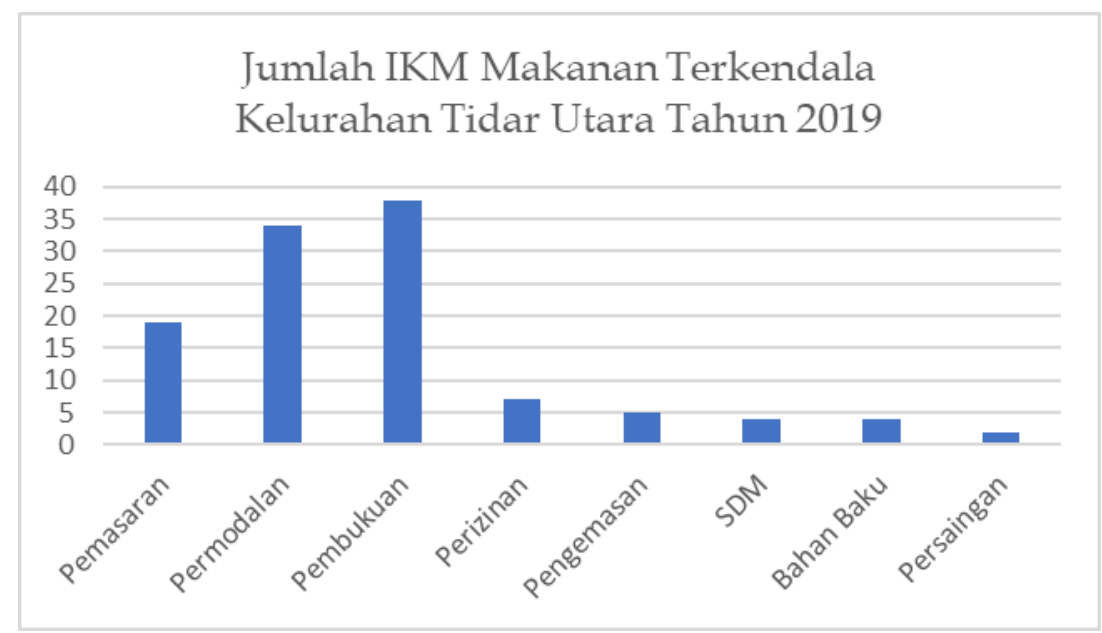

Grafik 1

Sumber: Data diolah menggunakan Excel, 2019

Dapat dilihat pada Grafik 1 perbandingan dari beberapa macam kendala yang dialami oleh IKM yang ada di Kelurahan Tidar Utara, khususnya pada sektor makanan. Tiga kendala utama tersebut yaitu kendala pemasaran, pemodalan, dan pembukuan. Dimana ketiga kendala tersebut memiliki presentase yang tinggi diantara kendala yang lainnya.

Gambar 1, dapat dilihat bahwa terdapat 30\% UKM di Kelurahaan Tidar Utara yang masih memiliki kendala di pemasaran. Faktor-faktor kendala pemsaran IKM Kelurahan Tidar Utara yaitu: 1. Strategi pemsaran kurang tepat, 2. Strategi pemasaran online yang kurang maksimal dll. (Widharta and Sugiharto, 2013) dalam penelitiannya mengungkapkan bahwa strategi penjualan merupakan rencana yang dibuat oleh perusahaan guna menentukan bagaimana dapat meningkatkan volume penjualan produknya serta dapat memenuhi dan memberikan kepuasan atas pemintaan dari konsumen. Tetapi, dalam hal pemasaran kesalahan juga sering kali terjadi yang disebabkan oleh minimnya pengetahuan atau kurangnya pengalaman dari pelaku usaha dalam menjalankan proses pemasaran. 


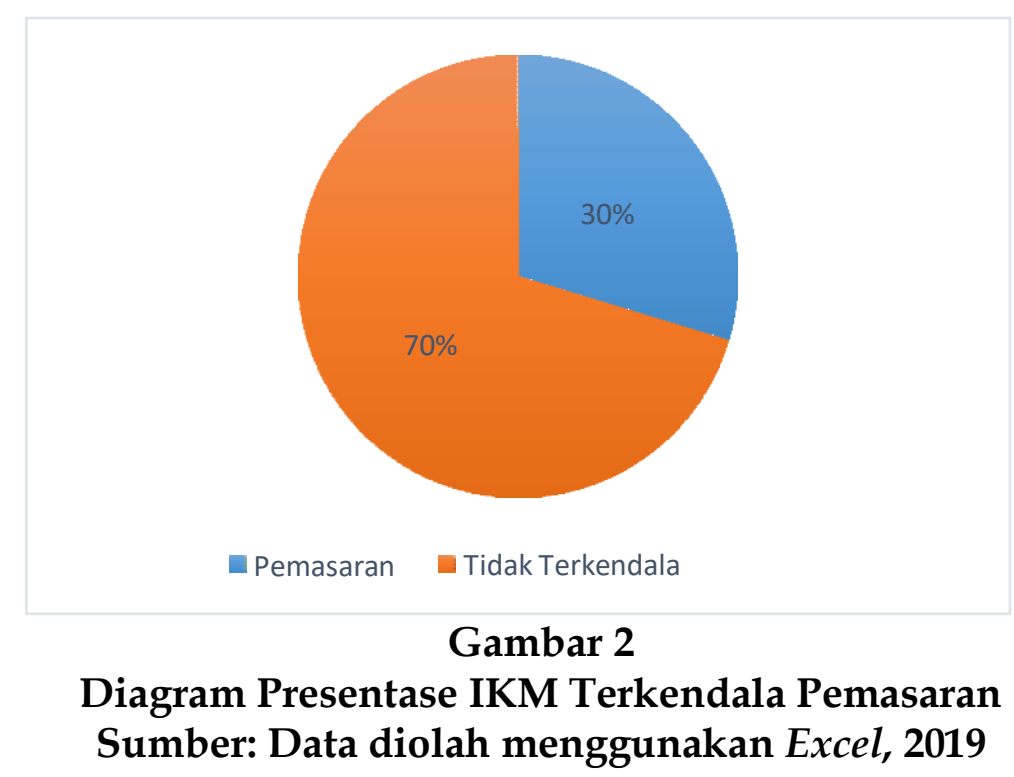

Di era digital marketing/internet marketing ini, pemasaran online menjadi strategi pemasaran dan promosi yang efektif dan efisien. Pelaku usaha mampu memanfaatkan blog dan media sosial yang sekiranya cocok dengan produk yang di pasarkan. Bagi perusahaan besar maupun kecil didorong agar mampu menguasai strategi pemasaran online dikarenakan sebagian besar penduduk Kota Magelang, tidak hanya Kota Magelang, bahkan di Indonesia sudah menjangkau internet. Peran Disperindag Kota Magelang untuk membantu para pelaku usaha yang masih kurang pengetahuan internet marketing dengan mengadakan sosialisasi di Kelurahan setempat dan diharapkan agar pelaku usaha mampu bergerak untuk mengatasi permasalahannya serta berlanjut pada tahap pengembangan usaha.

Masalah pemasaran mencapai angka 30\% sekalipun IKM sudah melakukan pemasaran online, tetapi masih belum maksimal. Selain tidak menguasai internet, pemasaran online yang belum maksimal pun juga menjadi kendala bagi beberapa pelaku usaha di Kelurahan Tidar Utara. Beberapa pelaku IKM sudah memasarkan produknya melalui media sosial seperti instagram, facebook, atau melalui situs marketplace. Tetapi pada kenyatannya, dalam praktek pemasaran online ini masih kurang maksimal sehingga mempengaruhi hasil atau pendapatan. Kendala tersebut dapat diselesaikan dengan cara memperluas pemasaran online melalui beberapa media social lainnya, atau dengan memilih salah satu saluran/media pemasaran online yang tepat untuk kemudian memfokuskan pemasaran di saluran tersebut serta mencari referensi strategi pemasaran online yang baik untuk mendapatkan lebih banyak konsumen. (Jatmika, 2016) Para ahli pemasaran setidaknya mampu memberikan pengetahuan tentang strategi dan penanganan bisnis yang baik kepada para pelaku IKM. 
Selain hal memasarkan online, jaringan pemasaran juga menjadi salah satu kendala yang dapat menghambat Usaha Kecil Menengah untuk berkembang. Upaya pengembangan jaringan pemasaran dapat dilakukan dengan berbagai macam strategi, contohnya dapat berkomunikasi dengan berbagai pusat informasi bisnis, asosiasi - asosiasi dagang baik di dalam maupun di luar negeri. Pendirian serta pembentukan berbagai pusat data bisnis UKM serta pengembangan situs UKM diseluruh kantor perwakilan pemerintah di luar negeri (Sriyana, 2010). Perlunya peran Pemerintah untuk mengadakan pelatihan bagi SDM UMKM secara rutin dan merata, terutama dalam hal pemasaran yang bertujuan untuk membentuk mitra usaha guna meningkatkan jaringan pemasaran (Kusuma et al., 2019).

Faktor lainnya yaitu tidak adanya branding untuk produk yang dipasarkan. Apabila suatu IKM/UKM tidak memiliki Brand dapat menjadi masalah yang cukup serius. Salah satu kendala pemasaran yang dialami beberapa IKM Kelurahan Tidar Utara disebabkan oleh pelaku usaha yang sering tidak memperhatikan pentingnya branding. Permasalahn ini sering kali luput dari para pelaku usaha tersebut sehingga, banyak pelaku IKM yang hanya fokus pada penjualan tanpa memerdulikan kualitas merk dari produknya sendiri. Khususnya pada IKM makanan ini, yang mana memiliki banyak peminat di daerah sekitar. Dalam upaya membesarkan bisnis, menjaga kualitas branding sangatlah penting karena, dengan kualitas branding dengan image yang baik, maka suatu produk akan mudah diingat oleh para konsumen dan hal tersebut juga mempengaruhi tingkat penjualan untuk semakin meningkat. Cara untuk mengatasi kualitas branding agar lebih baik untuk suatu produk IKM yaitu dengan melakukan analisis dengan metode SWOT (Strength, Weaknesses, Opportunities, Threats) pada suatu produk. Dengan begitu, dapat dianalisis tentang kekuatan, kelemahan, serta peluang maupun ancaman yang terjadi pada suatu produk. Dari hasil analisis, dapat ditemukan aspek yang paling menonjol dan apa yang dapat membedakan suatu produk dengan produk sejenis lainnya. Berdasarkan hasil, diharapkan para pelaku IKM dapat konsisten untuk lebih menonjolkan ciri khas produk sebagai bahan promosi, dan apabila pelaku IKM mampu konsisten dalam mmpertahankan ciri khas produk, hal tersebut mampu menentukan bagaimana kualitas suatu brand/merk. 


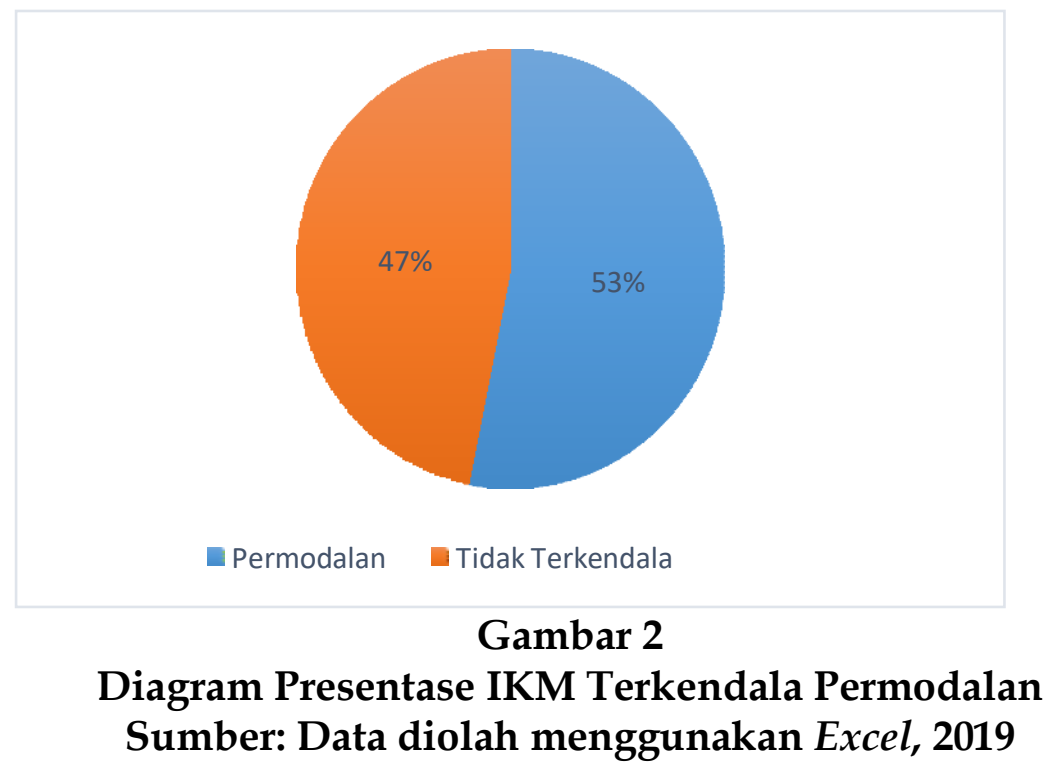

Kendala permodalan mencapai hingga $47 \%$ dari total keseluruhan tiga kendala utama. Jenis kendala ini sering terjadi pada usaha apapun, tak terkecuali pada bidang industri. Minimnya modal suatu usaha menjadi permasalahan mendasar di beberapa IKM makanan di Kelurahan Tidar Utara. Beberapa akibat yang ditimbulkan yaitu para pelaku IKM yang tidak bisa menaikkan jumlah produksi guna mencapai omset yang maksimal. Akibatnya, banyak pelaku IKM yang mengurungkan niat hanya untuk mengembangkan usaha ataupun membuka bisnis baru guna memperluas usaha.

Permasalahan yang sering ditemukan yaitu ketika para pelaku IKM yang merasa kesulitan untuk mencari modal dari bank tertentu dikarenakan persyaratan yang belum terpenuhi. Kekurangan dana untuk modal kerja maupun investasi, hal ini dapat disebabkan karena terbatasnya akses terhadap informasi, layanan, dan fasilitas keuangan yang disediakan. (Sriyana, 2010) Faktor modal termasuk lambannya akumulasi capital dan rendahnya surplus UKM menjadi salah satu sebab tidak munculnya berbagai usaha baru di luar sektor ekstratif. Maka dari itu, dalam hal pemberdayaan UKM, pemecahaan masalah modal ini penting dan memang harus dilakukan. Solusi yang dapat diterapkan ialah, para pelaku IKM dapat mencari serta memanfaatkan beberapa lembaga keuangan yang menawarkan modal pembiayaan dengan basis sistem equity crowdfunding (ECF). Equity crowdfunding atau penggalangan dana adalah suatu proses pengumpulan dana untuk sebuah proyek atau usaha oleh sejumlah orang yang biasanya dilakukan melalui platform online. Sistem equity crowdfunding (ECF) itu sendiri metodenya seperti membeli saham, berbeda dengan sistem peer to peer yang hanya meminjamkan dana saja. Manfaat semakin berkembangnya teknologi finansial saat ini menjadi peluang bagi startup dan juga usaha kecil menengah (UKM) ataupun IKM untuk mendapatkan pendanaan melalui sistem equity crowdfunding (ECF) tanpa terbebani kewajiban untuk membayar bunga dan pokok pinjaman. Beberapa situs pendanaan dengan sistem equity crowdfunding 
(ECF) yang dapat digunakan yakni kolase.com, akseleran.com, koinworks.com, gandengtangan.com, dan lain sebagainya

Disperindag Kota Magelang juga memiliki solusi tersendiri guna mengatasi permasalahan permodalan yang dialami oleh IKM makanan yang ada di Kelurahan Tidar Utara, yaitu dengan menyarankan para pelaku IKM untuk mengajukan KUR bagi para pelaku usaha yang sekiranya mengalami kekurangan modal. KUR atau Kredit Usaha Rakyat merupakan kredit atau pembiayaan untuk modal kerja atau investasi kepada debitur individu/perseorangan badan usaha dan kelompok usaha yang produktif serta layak namun belum memiliki agunan tambahan atau dengan kata lain agunan tambahan belum cukup. (Kusuma et al., 2019). Beberapa pelaku usaha beranggapan bahwa modal pinjaman dari Bank atau lembaga keuangan lainnya sulit diperoleh, disebabkan karena persyaratan secara administratife dan teknis yang diminta oleh Bank tidak mampu terpenuhi. (Nazifah \& Ikhwan, 2021) Para pelaku UKM harus mengetahui bahwasanya lembaga pemerintah (Bank dan Non-Bank) bersedia untuk membantu usaha bisnis mereka yang berasal dari pendanaan serta sistem modal. Karenanya, pendanaan dan sistem modal diharapkan bisnis UKM bisa jadi lebih baik. Oleh karena itu, Pemerintah juga harus memberikan penyuluhan kepada pelaku UKM secara berkala agar para pengusaha UKM tidak canggung untuk menerima bantuan dari Pemerintah dan LKM.

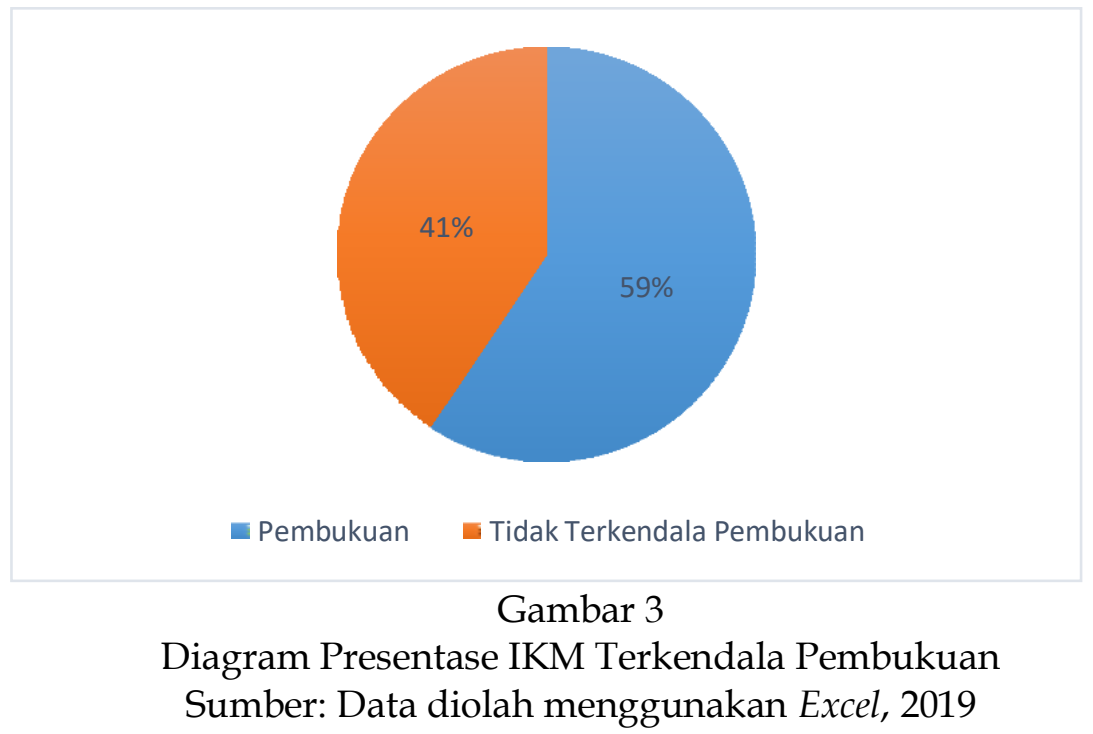

Bagi para pelaku usaha, manajemen pembukuan menjadi salah satu hal yang penting guna kepentingan akuntansi dan mengatur pemasukan serta pengeluaran usaha. IKM makanan di wilayah Kelurahan Tidar Utara sendiri, kendala pembukuan menjadi kendala dengan tingkat presentase tertinggi yaitu mencapai 59\% dibandingan dengan dua kendala utama lainnya. Penyebab dari kendala ini sering terjadi yaitu para pelaku IKM yang masih menyepelekan pencatatan keuangan dan masih menggunakan pencatatan 
manual. Banyak yang tidak sadar bahwa pembukuan secara manual ini dapat menjadi permasalahan yang cukup serius apabila tidak teliti. Pembukuan secara manual ini menjadi rawan terjadinya kerusakan, kehilangan, bahkan terjadi kesalahan pada pembukuan. Sehingga, para pelaku usaha tidak dapat menganalisa hasil dari penjualannya dengan benar.

Salah satu contoh kasus yang dialami pemilik IKM di salah satu kampung di Kelurahan Tidar Utara yaitu ketika pemilik IKM ingin melakukan rekap per minggu, tetapi laporan penjualan pada hari tertentu hilang, maka hal ini dapat menyebabkan laporan keuangan keseluruhan jadi berantakan. Kunci dari pembukuan adalah evaluasi bisnis yang baik. Dengan pembukuan yang baik dan benar, para pelaku usaha dapat menganalisa hasil penjualan dengan lebih tepat guna menjadi bahan pertimbangan mengambil keputusan selanjutnya. Pembukuan yang baik juga menjadi salah satu syarat wajib bagi semua pengusaha besar maupun kecil yang berniat ingin meminjam modal usaha kepada bank. Selain itu, apabila pembukuan tidak teratur, hal ini mengakibatkan sulitnya memprediksi antara keuntungan maupun pengeluaran yang bisa menjadi kerugian. (Nurani, 2019) Kendala pembukuan juga dipengaruhi oleh minimnya keterampilan yang kompeten dan sumber daya manusia yang tidak memiliki pengetahuan atau pembekalan dari pihak terkait tentang pentingnya ilmu manajemen dan bagaimana penerapannya. (Kusuma et al., 2019). Keterbatasan sumber daya manusia dalam hal mengelola pembukuan juga mempengaruhi sistem manajemen perusahaan yang menjadi lemah, terutama dalam hal akuntansi dan pemasaran produk.

Solusi yang dapat dilakukan guna mengatasi permasalahan ini yaitu mendorong para pelaku usaha agar mulai mengatur kembali cara melakukan pembukuan. Mulai belajar dengan melakukan pembukuan secara otomatis dengan bantuan software. Aplikasi yang dapat membantu mengatasi permasalahan ini yaitu dengan menggunakan InterActive MyProfit. InterActive MyProfit yaitu sebuah aplikasi kasir online yang didesain secara khusus untuk memudahkan para pemilik UMKM guna mengatur penjualannya, dimana aplikasi ini sangat cocok digunakan untuk berbagai bidang usaha kecil menengah. Dengan menggunakan aplikasi ini, diharapkan para pelaku usaha dapat belajar pembukuan yang mudah di era digital marketing ini, sesuai dengan petunjuk aplikasi. Selain itu, pelaku usaha tidak perlu bingung bagaimana melakukan rekap penjualan atau untuk menghitung omzet harian, karena rekap penjualan akantercetak oomatis melalui aplikasi. Ketakutan akan kehilangan laporan keuangan juga akan hilang, karena semua data yang tercatat di aplikasi dijamin lebih aman dengan adanya fasilitas penyimpanan di cloud server.

Pencatatan penjualan atau pembukuan bukan hanya ditekankan pada perusahaan yang berskala besar, tetapi juga diterapkan pada perusahaan yang kecil agar tidak mengalami kegagalan dalam mengetahui masalah keuangan dengan tepat. Dengan adanya pembukuan yang baik diawal usaha, maka suatu usaha kecil yang dalam tahap berkembang akan mengetahui dan memiliki kekuatan yang sehat secara finansial. Selain itu, usaha yang memiliki 
kontrol keuangan yang baik, memungkinkan untuk lebih mudah mendapatkan partner bisnis. (Kusuma et al., 2019) Pemerintah hendaknya melakukan pembinaan kepada semua UMKM secara bertahap dan bergantian, terutama dalam bidang sumber daya manusia. Pembinan sumber daya manusia diprioritaskan untuk pelatihan pembukuan dan juga organisasi. Hal ini bertujuan untuk meningkatkan efektivitas serta efisiensi kegiatan UMKM.

\section{KESIMPULAN}

Berdasarkan hasil penelitian dan analisis data diatas, dapat disimpulkan bahwa masih banyak kendala maupun permasalahan mendasar yang dialami IKM sektor makanan di Kelurahan Tidar Utara. Penyebab dari kendala pemasaran yang dialami oleh IKM makanan di Kelurahan Tidar Utara yaitu kesalahan penetapan strategi pemasaran serta kurangnya pengetahuan tentang digital/internet marketing. Minimnya modal suatu usaha menjadi permasalahan mendasar di beberapa IKM makanan di Kelurahan Tidar Utara. Permasalahan klasik yang sering ditemukan yaitu ketika para pelaku IKM yang merasa kesulitan untuk mencari modal dari bank tertentu dikarenakan persyaratan yang belum terpenuhi. Berdasarkan tiga kendala utama, kendala Pembukuan menempati presntase tertinggi. Penyebab dari kendala ini sering terjadi yaitu para pelaku IKM yang masih menyepelekan pencatatan keuangan dan masih menggunakan pencatatan manual.

\section{SARAN}

Saran yang dapat penulis berikan berdasarkan kendala yang menghambat IKM untuk berkembang yaitu: (1) Kendala Pemasaran. Pelaku usaha dapat memanfaatkan peluang dengan mengikuti pelatihan usaha yang diadakan oleh pemerintah setempat. Fokus pada pengembangan produk dan gencar melakukan promosi offline (brosur) maupun online (media sosial) guna memperluas usahanya. (2) Kendala Permodalan. Pelaku usaha dapat memilih opsi untuk mengajukan pinjaman dana melalui ECF (equity crowdfunding) atau KUR sebagai tambahan modal usaha dengan pertimbangan keuntungan, kemudahan dan keamanan dibandingan di Bank. (3) Kendala Pembukuan. Pelaku usaha secara sederhana dapat mulai melakukan pencatatan arus kas masuk maupun keluar secara manual atau pun dengan bantuan aplikasi, yaitu aplikasi InterActive MyProfit. Pelaku usaha juga sebaiknya melakukan pengecekan produk yang tersedia maupun yang sudah terjual sebagai bahan pencatatan yang berguna untuk aktivitas pemasarannya.

Kendala usaha Industri Kecil Menengah (IKM) dalam penelitian ini sangat membutuhkan perhatian dan kesadaran dari para pelaku usaha demi keberlangsungan di masa depan, serta bagaimana peran Pemerintah yang dapat membantu guna mengurangi permasalahan masyarakat dalam berwirausaha. 


\section{UCAPAN TERIMAKASIH}

Ucapan terima kasih penulis sampaikan kepada seluruh narasumber dan pendamping yang telah membantu dalam memberikan informasi yang dibutuhkan dalam penelitian ini. Ucapan terima kasih juga penulis sampaikan kepada seluruh pihak yang telah membantu hingga tulisan ini dapat selesai.

\section{REFERENSI}

Jatmika, R. T. D. (2016). Masalah yang dihadapi Usaha Kecil Menengah di Indonesia. Jurnal Ekonomi Syariah, 2(6).

Kusuma, S. C., Juliprijanto, W., \& Jalunggono, G. (2019). Analisis Pendapatan Umkm Di Sekitar Universitas Tidar Tahun 2018 (Studi khasus sebelum dan sesudah Universitas Tidar menjadi negeri di Tuguran kelurahan Potrobangsan Kecamatan Magelang Utara). DINAMIC: Directory Journal of Economic, 1(1), 6874.

Nazifah, M. N., \& Ikhwan, K. (2021). Analisis Faktor Kendala Industri Kecil Menengah (Studi Pada IKM Makanan di Kelurahan Tidar Utara Kota Magelang). Jurnal Manajemen Dan Bisnis Equilibrium, 7(1), 55-71.

Nurani, M. (2019). Analisis Faktor-Faktor Penghambat Pengembangan Usaha Mikro Kecil dan Menengah Dalam Persepektif Ekonomi Islam.

Setiaji, W. B., \& Khoirudin, R. (2018). Analisis determinan pendapatan usaha industri mikro kecil tahu di trunan,tidar selatan,magelang selatan kota magelang. Jurnal Dinamika Ekonomi Pembangunan, 1(3), 1-14.

Sri Adiningsih. (2013). Regulasi Dalam Revitalisasi Usaha Kecil dan Menengah di Indonesia.

Sriyana, J. (2010). Strategi Pengembangan Usaha Kecil dan Menegah (UKM) : Studi Kasus di Kabupaten Bantul. Simposium Nasional 2010, 79-103.

Taib, G., \& Roswita, R. (2018). Analisis Prospek Dan Kendala Pengembangan Produk Industri Pangan Lokal Di Sumatera Barat. Jurnal Teknologi Pertanian Andalas, 22(1).

Warcito, \& Ramly, A. T. (2020). Pemetaan Pelaku Usaha Mikro dan Kecil Di Kecamatan Cicurug. Jurnal Manajemen, 11(1), 1-10. https://doi.org/10.32832/jm-uika.v11i1.2861

Widharta, W. P., \& Sugiharto, S. (2013). Penyusunan Strategi dan Sistem Penjualan Dalam Rangka Meningkatan Penjualan Toko Damai. Manajemen Pemasaran Petra, 2(1), 1-15. 